\title{
Resilience in Water Infrastructures: A Review of Challenges and Adoption Strategies
}

\author{
Apurva Pamidimukkala, Sharareh Kermanshachi *, Nikhitha Adepu and Elnaz Safapour \\ Department of Civil Engineering, University of Texas at Arlington, Arlington, TX 76019, USA; \\ apurva.pamidimukkala@mavs.uta.edu (A.P.); nikhitha.adepu@mavs.uta.edu (N.A.); \\ elnaz.safapour@mavs.uta.edu (E.S.) \\ * Correspondence: Sharareh.kermanshachi@uta.edu
}

check for

updates

Citation: Pamidimukkala, A.; Kermanshachi, S.; Adepu, N.; Safapour, E. Resilience in Water Infrastructures: A Review of Challenges and Adoption Strategies. Sustainability 2021, 13, 12986. https://doi.org/10.3390/ su132312986

Academic Editors: Gyan Chhipi Shrestha, Nicolas Beauchamp, Ianis Delpla and Bingyi Kang

Received: 28 October 2021

Accepted: 23 November 2021

Published: 24 November 2021

Publisher's Note: MDPI stays neutral with regard to jurisdictional claims in published maps and institutional affiliations.

Copyright: (c) 2021 by the authors. Licensee MDPI, Basel, Switzerland. This article is an open access article distributed under the terms and conditions of the Creative Commons Attribution (CC BY) license (https:/ / creativecommons.org/licenses/by/ $4.0 /)$.
Abstract: An increase in the number and strength of natural catastrophes experienced over the past few decades has accelerated the damage sustained by infrastructures. Drinking water and wastewater infrastructure systems are critical aspects of a healthy environment, and their ability to withstand disasters is vital for effective disaster response and recovery. Although numerous studies have been conducted to determine the challenges that natural disasters render to water infrastructures, few extensive examinations of these challenges have been conducted. The goal of this study, therefore, was to identify and categorize the challenges related to the resilience of drinking water and wastewater infrastructures, and to determine the strategies that most effectively minimize their unintended consequences. A comprehensive evaluation of the existing literature was conducted, and 537 publications were collected. After extensive screening, 222 publications were selected for rigorous evaluation and analysis based on the data collection methods and other criteria. A total of fifty-one (51) challenges were determined and classified, within the following five categories: environmental, technical and infrastructure, social, organizational, and financial and economic. The challenges were then ranked within each category according to their frequency of occurrence in previous research. The results reveal that climate change, aging infrastructure, lack of infrastructure capital, population growth, improper maintenance of water infrastructure, and rapid urbanization are the most frequently cited challenges. Next, 30 strategies and approaches were identified and categorized into either preventive or corrective actions, according to their implementation time. The findings of this study will help decision- and policymakers properly allocate their limited funding to enhance the robustness of their water infrastructures before, during, and after natural hazards.

Keywords: water; resilience; wastewater; infrastructure; challenges

\section{Introduction}

The U.S. government enacted the Clean Water Act in 1972 and the Safe Drinking Water Act in 1974 to provide its citizens with safe and clean water [1]. Since then, attempts have been made to protect the water infrastructure and provide safe water for the healthy functioning of society. Safe, clean water is an essential part of our day-to-day lives. Reinforcing and preparing the water infrastructure for any sort of circumstance and making our drinking and wastewater infrastructure resilient in the face of natural hazards is of great importance $[2,3]$. It is crucial to health, as it secures the environment, increases economic growth by providing employment opportunities, and provides individuals with water that can be used for a variety of purposes (drinking, cooking, and recreation) [4,5].

Natural hazards are occurring more frequently, and we cannot keep them from occurring $[3,6]$, which results in a transition in risk management. Rather than decreasing exposure or the odds of a hazard occurrence, decision-makers are increasingly focusing on strengthening the resilience and reducing the vulnerability of infrastructures [7]. Over time, various definitions of and approaches to resilience have been touted. From the point of view of [8], the capacity to minimize the size and intensity of natural disasters is referred to 
as infrastructure resilience. The ability of a resilient infrastructure or organization to foresee, endure, adjust to, and swiftly recover from a potentially disastrous incident determines its efficacy.

In the opinion of researchers [9], the progress of human society is associated with critical infrastructure. Researcher [10] took this one step further by espousing that the maintenance of critical infrastructures is vital for the socio-economic system. According to the United States Environment Protection Agency (USEPA), the United States has spent billions of dollars to replace, repair, and maintain drinking water, wastewater, and the stormwater infrastructure during the past few years. The requirement for an infrastructure investment is justified, as water is crucial to Americans' physical and economic lives [11]. Most existing distribution lines, treatment plants, and sewer lines are at least 100 years old. The replacement era has arrived, and our common concern now is to meet public health and other programmatic goals [12]. At present, all government levels are taking steps toward building resilient infrastructures and communities [13].

The following objectives were developed to determine the challenges and strategies that contribute to the resilience of drinking water and wastewater infrastructures: (1) identify the challenges, (2) classify the challenges, (3) prioritize and rank the challenges based on the frequency with which they appear in the literature, (4) identify the strategies and approaches, and (5) classify the strategies and approaches based on the time of their implementation. This study can significantly help researchers and management authorities to be aware of the challenges and management strategies that can enhance the resilience of the drinking water and wastewater infrastructure.

\section{Research Methodology}

Figure 1 depicts the systematic research framework that was developed to fulfill this study's objectives. A thorough literature search was conducted, using search engines, including Google Scholar, Science Direct, Scopus, Inspec, and ProQuest, to acquire relevant articles. The selected publications were then scrutinized based on the journal's name, data collection method, and year of study. After the five main objectives were achieved and studied, the results were analyzed and discussed.

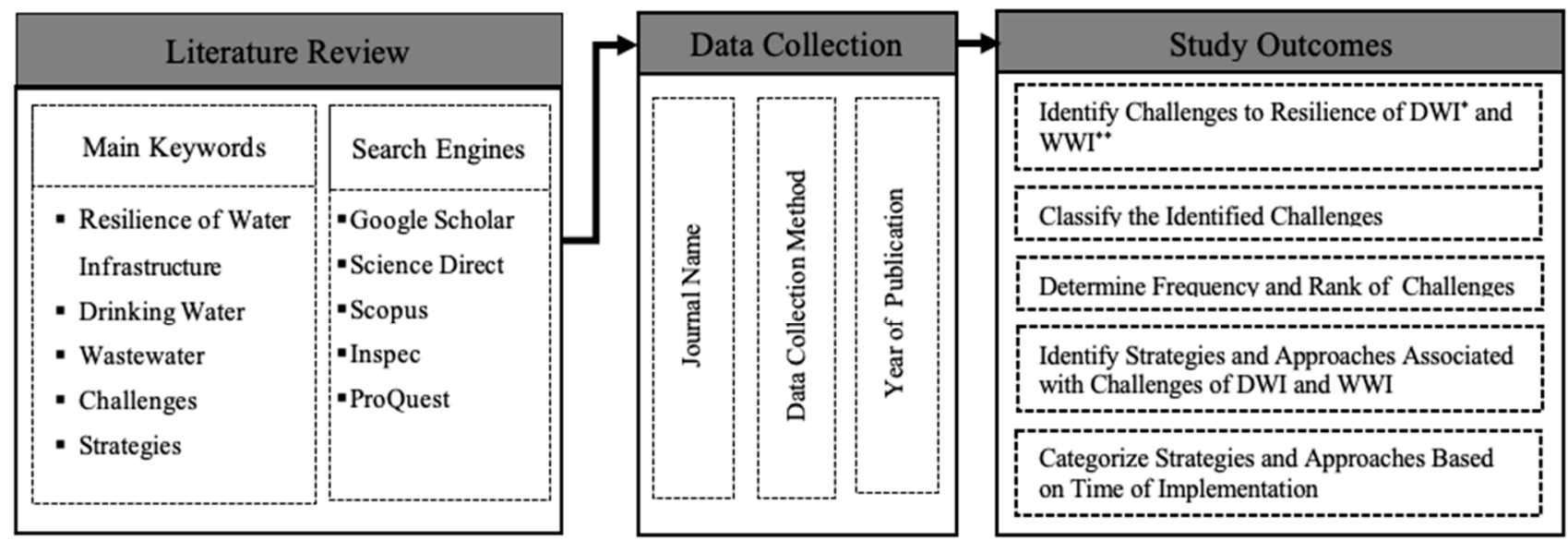

DWI refers to Drinking Water Infrastructure $W W I^{*}$ refers to Wastewater Infrastructure

Figure 1. Research Methodology.

\section{Data Collection}

The selection and review process of articles for this research are depicted in Figure 2. It began by entering the following keywords into multiple search engines to gather pertinent scholarly articles: resilience of water infrastructure, drinking water, wastewater, challenges 
to the resilience of drinking water and wastewater infrastructures, and strategies to enhance the water infrastructure resilience. As a result, 537 published journal articles, conference proceedings, dissertations, and research reports on the resilience enhancement of drinking water and wastewater infrastructures were collected. First, the authors excluded the works published before the year 2000, as most of the challenges and strategies discussed in the published articles after the year 2000 covered those discussed in studies published before the year 2000. Next, the titles and abstracts were reviewed by the authors, and relevant articles were included. Lastly, the authors screened full-text papers, and 222 articles were retained for a detailed review.

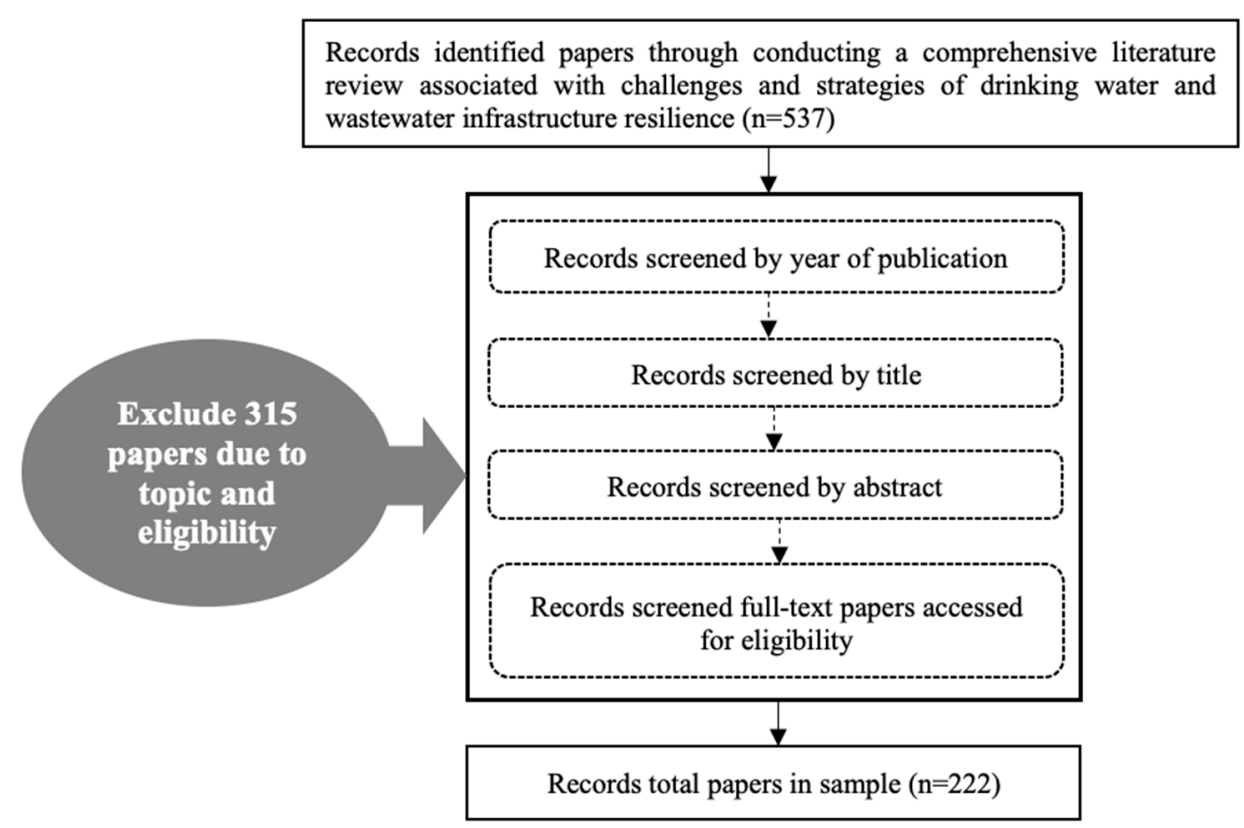

Figure 2. Process of Review and Selection of Article.

\subsection{Journal Name}

Table 1 shows a distribution of the articles according to their sources and scientific field and shows that the authors enhanced the study database by analyzing various articles. The top five selected journals were Water, Journal of Infrastructure Systems, Journal of Water Resources Planning and Management, Water Research, and Water Science and Technology, representing $11 \%, 10 \%, 10 \%, 8 \%$, and $7 \%$ of the articles in the database, respectively. The publishers of the peer-reviewed journals are the Multidisciplinary Digital Publishing Institute (MDPI), the American Society of Civil Engineers (ASCE), Elsevier, and the International Water Association.

Table 1. Frequency of Articles Based on Journals.

\begin{tabular}{cccc}
\hline Journal Name & Scientific Field & Frequency & Percentage \\
\hline Water & Water science and technology & 19 & $11 \%$ \\
Journal of Infrastructure Systems & Civil engineering & 17 & $10 \%$ \\
Journal of Water Resources Planning and & Water resources management & 17 & $10 \%$ \\
Management & Water science and technology & 15 & $8 \%$ \\
Water Research & Management of water quality & 13 & $7 \%$ \\
Water Science and Technology & Public administration & $9 \%$ & $5 \%$ \\
Public Works Management and Policy & System engineering & 9 & $5 \%$ \\
Journal of Extreme Events & Structural engineering & & 9 \\
Journal of Structural Engineering & & & \\
\hline
\end{tabular}


Table 1. Cont.

\begin{tabular}{|c|c|c|c|}
\hline Journal Name & Scientific Field & Frequency & Percentage \\
\hline International Journal of Disaster Risk Reduction & Disaster management & 8 & $4 \%$ \\
\hline Risk Analysis & Engineering and social science & 7 & $4 \%$ \\
\hline Environmental Science and Technology & Environmental science, technology, and policy & 7 & $4 \%$ \\
\hline Natural Hazards & Disaster management & 7 & $4 \%$ \\
\hline Global Environmental Change & Environmenta engineering & 6 & $3 \%$ \\
\hline $\begin{array}{c}\text { Journal of Construction Engineering and } \\
\text { Management }\end{array}$ & Construction engineering & 5 & $3 \%$ \\
\hline Sustainability & Sustainable development & 5 & $3 \%$ \\
\hline Urban Water Journal & Water infrastructure systems & 4 & $2 \%$ \\
\hline Journal of Environmental Management & Environmental engineering & 3 & $2 \%$ \\
\hline Journal of Environmental Engineering & Environmental engineering & 3 & $2 \%$ \\
\hline Others & Engineering and social science & 12 & $7 \%$ \\
\hline Total & & 177 & $100 \%$ \\
\hline
\end{tabular}

Note: Other Journals are those that have a frequency of one, such as Procedia Engineering.

\subsection{Data Collection Method}

The most often used approaches for data collection are literature reviews, surveys, interviews, questionnaires, experiments, observations, and case studies. Figure 3 illustrates the distribution of published articles based on their data gathering procedures. Literature review is the most common method of data collecting, accounting for $36 \%$ of all publications. Surveys and interviews are the second most frequently used practice, contributing to $32 \%$ of all practices. Case studies rank third, comprising $18 \%$ of all practices, while only $14 \%$ of data is gathered through experiment and observation.

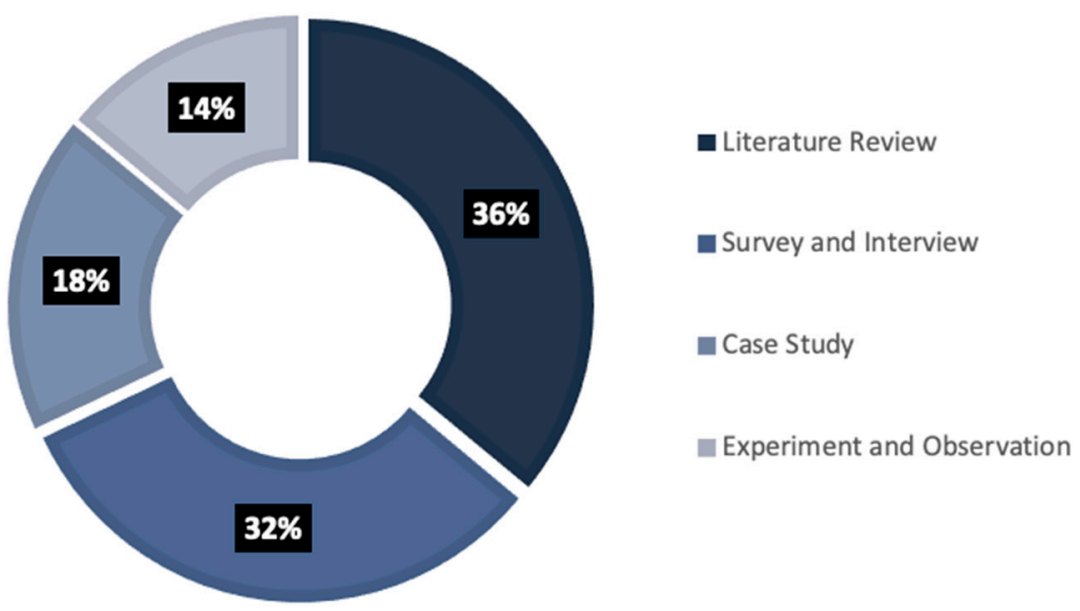

Figure 3. Distribution of Publications According to the Data Collection Approaches.

\subsection{Year of Study}

As presented in Figure 4, articles published from 2000-2020 were analyzed and sorted into two-year intervals. From Figure 4, it is evident that there was a constant increase in the number of publications after 2010; however, the highest frequency of publications (45) occurred between 2019 and 2020. As the need for a more resilient water infrastructure grows in tandem with the growing number of global difficulties, efforts are being made to understand the causes of the increased frequency of disasters and develop approaches to overcome them. 


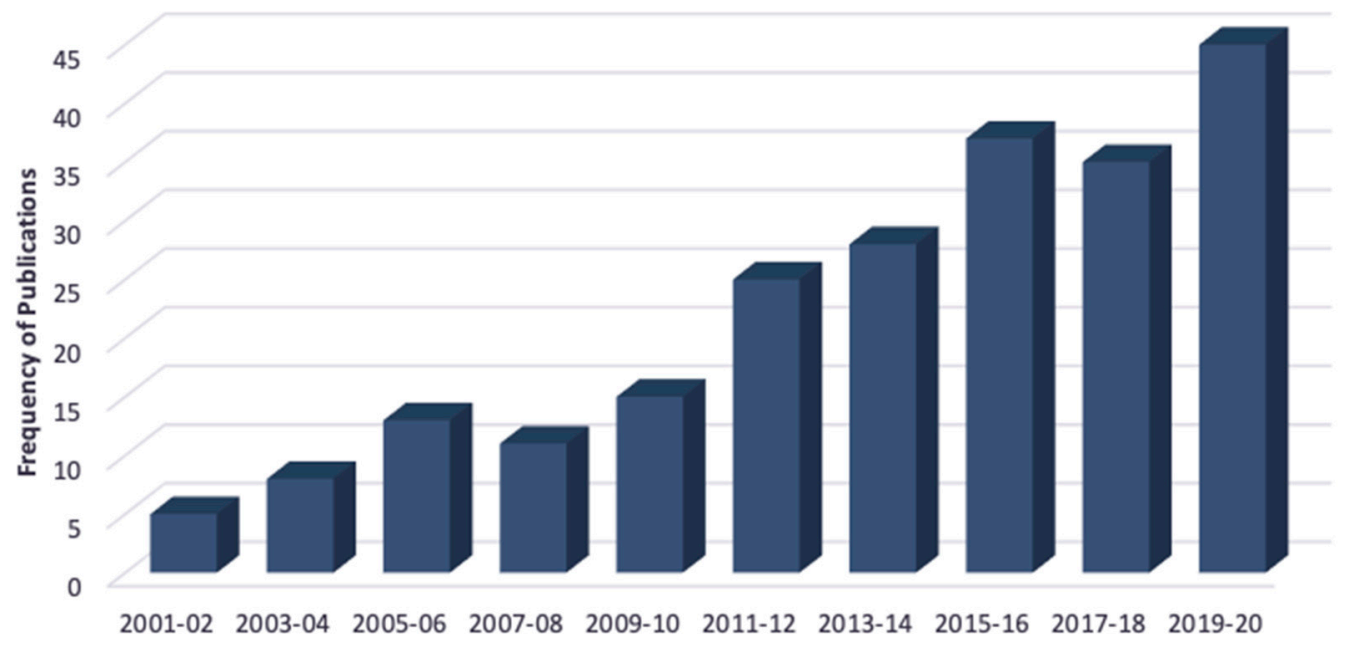

Figure 4. Distribution of Articles Based on the Year of Publication.

\section{Identification and Classification of Challenges to Drinking Water and Wastewater Infrastructure Resilience}

The full texts of the gathered papers were evaluated to determine the challenges to the resilience of the drinking water and wastewater infrastructure. A total of fifty-one (51) challenges were determined and categorized into five groups: environmental, technical and infrastructure, social, organizational, and financial and economic. The challenges were then ranked within each category according to their frequency of occurrence in previous research. For example, rank one indicates the most commonly stated challenge in the reviewed literature. Tables 2-6 summarize the categories, challenges, frequencies, and rankings.

\subsection{Environmental}

Ecosystems and the environment contribute significantly to the wellbeing of humankind [14]. For example, risk reduction and resilience in the face of disasters can be accomplished through an effective ecosystem and environmental management. However, as presented in Table 2, the environmental category consists of ten challenges, among which climate change (E1) was noted 55 times as a significant challenge in the reviewed literature.

Table 2. List of Environmental Challenges with Frequency and Rank.

\begin{tabular}{|c|c|c|c|c|}
\hline ID & Environmental Challenge & Previous Study & Frequency & Rank \\
\hline E1 & Climate change & {$[4,15]$} & 55 & 1 \\
\hline E2 & Flooding & {$[16,17]$} & 43 & 2 \\
\hline E3 & Extreme weather conditions & [17-19] & 38 & 3 \\
\hline E4 & Drought & {$[20,21]$} & 35 & 4 \\
\hline E5 & Earthquakes & [19] & 31 & 5 \\
\hline E6 & Concentration of dissolved salts, groundwater salinity & {$[22]$} & 29 & 6 \\
\hline E7 & Urban non-point source pollution & {$[23,24]$} & 27 & 7 \\
\hline $\mathrm{E} 8$ & Combined sewer overflows (CSOs) & {$[2,25]$} & 17 & 8 \\
\hline E9 & Direct and indirect lack of water & {$[26]$} & 12 & 9 \\
\hline E10 & Water pollution & {$[27,28]$} & 9 & 10 \\
\hline
\end{tabular}

Changes in the environment create new obstacles and lengthen the recovery time of the reconstruction process, and as we are not usually able to foresee natural catastrophes or their severity, it is vital to be prepared for any type of disaster. Any alterations in the climate impact society, the economy, and the environment, and our changing climate is one of the critical challenges to achieving and maintaining a resilient water infrastructure [29]. 
Flooding and vulnerability to heavy rains was the second most cited challenge of the environmental category. A resilient infrastructure should be able to withstand and recover from any kind of future disaster, but the history of damages created by floods shows us how weakly our engineering and economic systems were designed (Jonkman and Dawson 2012). The need for infrastructures that are resilient to floods is greater than ever because of the increasing number of floods and the intensity of damages that they wreak. To fully comprehend and quantify flood risks, flood maps, along with a comprehensive analysis of loads and inundations, and an impact analysis, is needed [16].

Extreme weather conditions are the third most noted barrier of this category. They consist of either the highest or the lowest temperatures that will cause a surge in extreme weather events, such as floods, droughts, wildfires, erosion, turbidity, collection of debris, and many more issues [18]. These conditions are hard to manage and negatively impact water quality, thereby endangering human health [19]. The next most frequently referred to environmental challenges are droughts and earthquakes, respectively. The authors of [20] noted that earthquakes and droughts have the most risk factors for water infrastructures, as any disaster that causes damage to significant aqueduct systems will have a greater impact on the supply of water.

\subsection{Technical and Infrastructure}

The infrastructure refers to a collection of systems and networks, such as water distribution, energy production, telecommunications, and transportation, which are vital to the function of society. Inadequate operation of various infrastructures can have a detrimental effect on all of an area's activity. Although the recovery process after a disaster facilitates the establishment of robust infrastructures, it is frequently fraught with barriers [30]. As shown in Table 3, the technical and infrastructure category includes twelve challenges. The most frequently cited challenge is an aging infrastructure.

Table 3. List of Technical and Infrastructure Challenges with Frequency and Rank.

\begin{tabular}{|c|c|c|c|c|}
\hline ID & Technical and Infrastructure Challenge & Previous Studies & Frequency & Rank \\
\hline $\mathrm{T} 1$ & Aging infrastructure & {$[31,32]$} & 51 & 1 \\
\hline $\mathrm{T} 2$ & Improper maintenance of water infrastructure & {$[4,33]$} & 47 & 2 \\
\hline $\mathrm{T} 3$ & Traditional wastewater treatment methods & {$[34,35]$} & 39 & 3 \\
\hline $\mathrm{T} 4$ & The interdisciplinary nature of infrastructure systems & {$[36,37]$} & 32 & 4 \\
\hline $\mathrm{T} 5$ & Loss of disinfectant residuals & [38] & 26 & 5 \\
\hline T6 & Escalating physical threats & {$[39,40]$} & 21 & 6 \\
\hline $\mathrm{T} 7$ & Redundancy in the water distribution systems & [41] & 16 & 7 \\
\hline $\mathrm{T} 8$ & Interdependencies of water and wastewater infrastructure to electric power & {$[42,43]$} & 14 & 8 \\
\hline T9 & Storage capacity in the wastewater collection system & {$[44]$} & 14 & 9 \\
\hline $\mathrm{T} 10$ & $\begin{array}{c}\text { Backup power and structural stability of drinking and wastewater } \\
\text { treatment and pumping facilities }\end{array}$ & [41] & 7 & 10 \\
\hline $\mathrm{T} 11$ & Inefficient pond sand filters & {$[45]$} & 4 & 11 \\
\hline $\mathrm{T} 12$ & Unauthorized structures & [46] & 3 & 12 \\
\hline
\end{tabular}

The issue of an aging infrastructure has grown more significant in recent years. Many infrastructures and equipment were developed or installed in the 1950s and early 1960s [31], and are reaching the end of their usefulness. However, developing a sustainable infrastructure demands a considerable financial investment to keep the essential infrastructure components and networks in excellent working order [32]

The next most frequently cited barrier of this category is improper maintenance of the water infrastructure. The direct proportion between the aging infrastructure and its maintenance is creating large barriers. The authors of [4] cited that a poor maintenance program might pose an external danger to water users and regulators; therefore, proper infrastructure management and maintenance must be considered as one of the significant challenges to the drinking and wastewater infrastructure [33]. 
The use of traditional wastewater treatment technologies is the third most often cited challenge [34]. Conventional methods such as water-flush toilets, combined sewerage, and centralized treatment have not been harmonized, and diluting pathogen- and hazardous-substance-containing wastewater streams, such as heavy metals and organic micropollutants, complicate treatment [35].

The interdisciplinary nature of a critical infrastructure is the fourth most mentioned barrier of this category, and it needs a greater understanding as it creates real challenges around the domain [37]. To begin with, there is no unified lexicon, thus multiple names for the same notion might exist. Similar terms can have distinct meanings, which necessitates constant translation, and as a result, attempting to integrate findings that are based on mutually compatible assumptions is sometimes challenging [36].

Escalating physical threats to the water infrastructure is the next most commonly discussed technical and infrastructure barrier. As physical risks are increasing, it is essential to create strategies that can detect the multifaced cyber and physical threats that cause damages to physical components, such as pumps, valves, tanks, as well as to the supply and quality of water [39].

\subsection{Social}

The social science literature defines resilience as "the intricate network of social connections, characteristics, and capacities that enable a community to adapt to the hazards it faces" [47,48]. As a result, communities must be prepared for disaster mitigation and resilience building in order to avoid the most adverse impacts of disasters and recover as quickly as possible. As shown in Table 4, population growth was discussed 47 times in the reviewed literature as one of the most critical challenges. In the studies conducted by $[4,49,50]$, population growth was mentioned as the greatest challenge to the water infrastructure because it has made ensuring water quantity and quality increasingly difficult.

Table 4. List of Social Challenges with Frequency and Rank.

\begin{tabular}{ccccc}
\hline ID & Social Challenge & Previous Studies & Frequency & Rank \\
\hline S1 & Population growth & {$[49,50]$} & 47 & 1 \\
S2 & Rapid urbanization & {$[51,52]$} & 45 & 2 \\
S3 & Lack of awareness of disaster response and recovery & {$[12,53]$} & 36 & 3 \\
S4 & Lack of community engagement and responsibility & {$[54-56]$} & 28 & 4 \\
S5 & Drastic increase in water demand & {$[57]$} & 26 & 5 \\
S6 & Lack of trust in public & {$[54,58]$} & 25 & 6 \\
S7 & Negative public opinion & {$[53]$} & 19 & 7 \\
S8 & Disaster migration & {$[52]$} & 14 & 8 \\
S9 & Crisis communication needs & {$[58]$} & 7 & 9 \\
S10 & Inability to use emerging information and communication technology & {$[59]$} & 5 & 10 \\
\hline
\end{tabular}

Rapid urbanization was the second most cited social issue because it results in rapid population growth [51]. Effective urban water policies and designs that can be adapted to changes in needs are essential to managing the water infrastructure issues caused by an increase in population and urbanization [52]. For example, due to urbanization, climate change results in increased rainfall and an increase in impermeable surfaces, both of which contribute to a decrease in the resilience of a system [60].

The public's lack of awareness and knowledge about disaster response and recovery adds to the recovery time and was identified as third most cited social barrier. Having a mentally strong society builds encouragement and trust among its members. The authors of $[12,53]$ believe that implementation of the resilience concept, and maintenance and promotion of sustainable infrastructures are imperative actions that should be put forward in designing drinking water infrastructures.

Lack of community engagement and responsibility and a drastic increase in the demand for water are the next most often cited social challenges. A lack of community engagement results in a respective decline in the quality and quantity of services and re- 
sources received in response to the disaster [55,61]. Furthermore, as the demand for water increases, it places a burden on the maintenance and distribution of water for domestic, agricultural, industrial, and recreational purposes, posing a threat to the existing infrastructure and challenging the design and construction of future infrastructural facilities $[62,63]$.

\subsection{Organizational}

The organizational category encompasses thirteen challenges, among which the most frequently cited was lack of data reliability, quality, and accessibility, as shown in Table 5. According to [64], obtaining meaningful and reliable data has always been a problem in quantifying resilience. In the same way that data from risk and vulnerability analyses assists decision-makers in recognizing problems, vulnerabilities, and allocating resources, the lack of quality information has a detrimental effect on society and other interdependencies $[7,65]$.

Pooling risks in a professional service provider is the second most cited organizational barrier. The author of [66] says that pluralist institutions attempt to create fulfilling solutions to rural water issues for diverse ways of organizing, particularly as it relates to operational and financial concerns, through risk pooling and networking at scale.

Table 5. List of Organizational Challenges with Frequency and Rank.

\begin{tabular}{|c|c|c|c|c|}
\hline ID & Organizational Challenge & Previous Study & Frequency & Rank \\
\hline $\mathrm{O} 1$ & Lack of data reliability, quality, and accessibility & {$[7,64]$} & 44 & 1 \\
\hline $\mathrm{O} 2$ & Pooling risks in professional service provider & {$[66,67]$} & 35 & 2 \\
\hline $\mathrm{O} 3$ & Lack of sustainable and system planning & {$[2,68]$} & 31 & 3 \\
\hline $\mathrm{O} 4$ & Speed and scale of response & {$[57,69]$} & 27 & 4 \\
\hline O5 & Poor solid waste management & [51] & 23 & 5 \\
\hline O6 & Providing services to refugees & {$[69,70]$} & 19 & 6 \\
\hline O7 & Disposal of hospital wastes & {$[71-73]$} & 18 & 7 \\
\hline O8 & Lack-of-awareness campaigns & [70] & 11 & 8 \\
\hline O9 & Inadequacy of qualified human resources & [46] & 9 & 9 \\
\hline $\mathrm{O} 10$ & Lack of regulatory frameworks & [46] & 8 & 10 \\
\hline O11 & Shortage of supporting tools and systems & {$[74]$} & 4 & 11 \\
\hline $\mathrm{O} 12$ & Lack of integrated framework and technological solutions & [66] & 3 & 12 \\
\hline $\mathrm{O} 13$ & Lack of comprehensive strategies in measuring resilience performance & [74] & 3 & 13 \\
\hline
\end{tabular}

Currently, the performance of a water and wastewater utility is determined not only by the delivery of basic services or the processing of wastewater with sufficient quality levels, but also by other factors such as sustainability [35]. Thus, a lack of sustainability and system planning is the third most mentioned barrier in this category, as failures in the planning process can cause negative consequences [68].

As presented in Table 5, the speed and scale of a response is the next most cited organizational barrier, and [69] espoused that the construction industry faces these challenges. The reasons behind the delays in response time are an inappropriate water infrastructure, disparities in the performance and unmonitored self-supply, lack of sustainable and innovative system planning, and pooling risks in a professional service provider [57].

Poor solid waste management is the fifth most referred to barrier in the organizational category. Solid waste management is a problem for metropolitan regions of all sizes, from megacities to tiny towns and big villages [46]. Cities produce enormous volumes of solid garbage and have everything from non-existent collection methods to inefficient disposal that pollutes the air, water, and land. Open and filthy landfills lead to the pollution of drinking water, as well as to the spread of illness and sickness [51].

\subsection{Financial and Economic}

The financial and economic category includes six challenges that might be considered as economic indicators for a successful recovery. As illustrated in Table 6, the lack of infrastructure capital was the most-cited financial and economic barrier, with the frequency 
of 49. Adequate funding is absolutely vital to the extensive investments that will be necessary to repair old infrastructures, bring them into compliance with more stringent health and environmental laws, and ensure future service quality [36].

Table 6. List of Financial and Economic Challenges with Frequency and Rank.

\begin{tabular}{ccccc}
\hline ID & Financial and Economic Challenge & Previous Studies & Frequency & Rank \\
\hline FE1 & Lack of infrastructure capital & {$[1,36]$} & 49 & 1 \\
FE2 & Low economic levels of the public & {$[75]$} & 29 & 2 \\
FE3 & Unemployment issues & {$[70]$} & 27 & 3 \\
FE4 & Inability to pay utility bills & {$[70]$} & 23 & 4 \\
FE5 & Socio-economic status & {$[76,77]$} & 21 & 5 \\
FE6 & Competition for local employment & {$[78]$} & 19 & 6 \\
\hline
\end{tabular}

As presented in Table 6, the next two most cited challenges are related to the population's low economic status and unemployment issues [70]. The author of [75] cited that human health is at risk due to inappropriate access to portable water, particularly in low- and middle-income nations as economic issues such as unemployment hinder the procurement of safe drinking water [70]. The inability to pay utility bills, socio-economic status, and competition for local employment are the last three significant challenges of this category. A state's capacity to respond to the rising water-sector demands is hampered by non-existent financial resources [76]. When utility customers do not pay their bills, it is difficult (or impossible) for municipalities to continue delivering services [70]. Furthermore, the interlinking nature of the socio-economic status is responsible for the unequal distribution of infrastructure facilities in many developing countries. This discrepancy in the socioeconomic status makes it harder for people in low-income groups to manage emergency resources during recovery from a disaster [78].

\subsection{Top Five Highest Frequency Challenges}

The top five most frequently cited challenges, depicted in Figure 5, fall into five categories: environmental, technical and infrastructure, financial and economic, social, and organizational. Climate change (E1), which belongs to the environmental category, scored the highest frequency (55); aging infrastructure (T1), which falls under the technical and infrastructure category, received the second-highest frequency (51); and lack of infrastructure capital (FE1), which belongs to the financial and economic category, received the third-highest frequency (49) among all identified challenges.

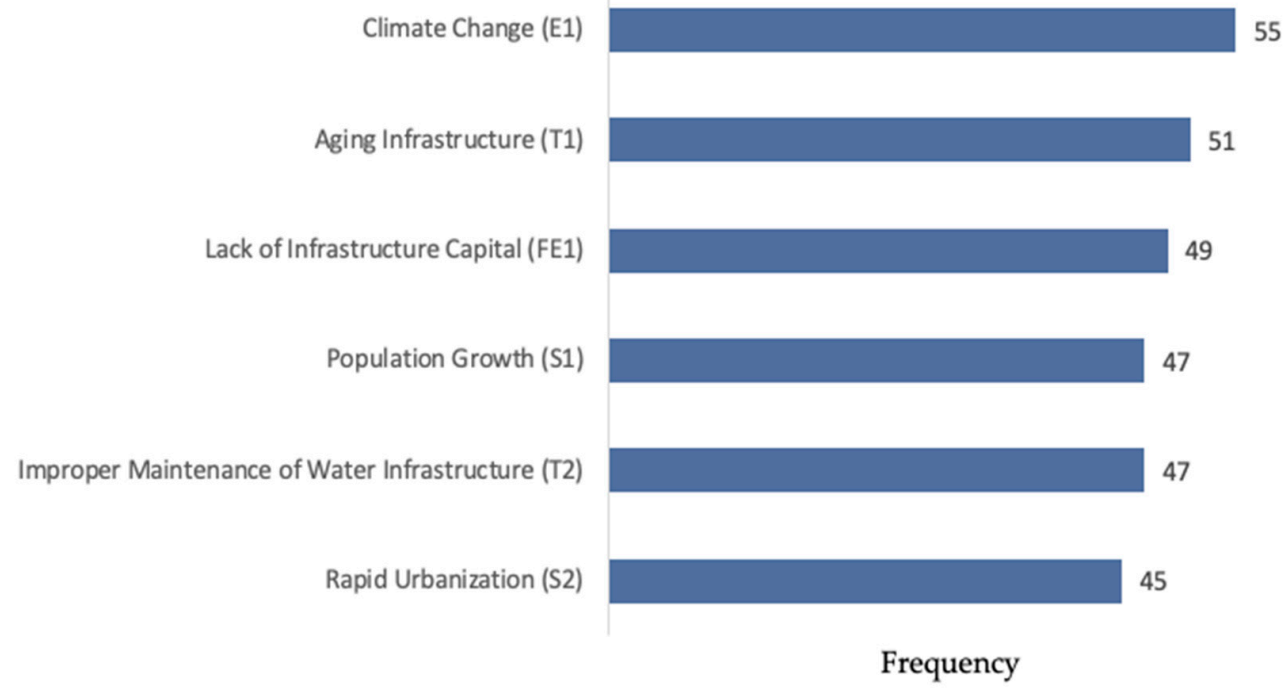

Figure 5. Top Five Highest Frequency Challenges. 


\section{Strategies and Approaches for Achieving a Resilient Drinking Water and Wastewater Infrastructure: Preventive and Corrective Actions}

Appropriate strategies and approaches, based on the identified challenges, can be implemented to enhance the resilience of the drinking water and wastewater infrastructure. Preventive strategies should be adopted prior to a disaster, while corrective methods should be implemented following a disaster. Of the 30 strategies and approaches that were found to be effective, seventeen (17) were classified as preventive, while the other thirteen (13) were classified as corrective, based on their implementation time. Table 7 presents the strategies and approaches in terms of their application, time of implementation, and the related challenges.

Table 7. List of Strategies and Approaches and their Related Challenges.

\begin{tabular}{|c|c|c|c|c|}
\hline$\#$ & Strategy or Approach & Type & Challenge & Previous Studies \\
\hline 1 & Geographic Information System (GIS) & Preventive & $\mathrm{T} 1, \mathrm{~T} 4, \mathrm{~T} 6$ & [79] \\
\hline 2 & Examining decisions on management techniques & Corrective & $\mathrm{E} 1, \mathrm{E} 4, \mathrm{E} 5, \mathrm{E} 9, \mathrm{~T} 7$ & {$[15,29]$} \\
\hline 3 & Mary Douglas cultural theory & Preventive & $\mathrm{O} 1, \mathrm{O} 2$ & {$[66]$} \\
\hline 4 & Educating people about Disaster Response and Recovery (DRR) & Preventive & S3, S10, O6, O9, FE5 & {$[80,81]$} \\
\hline 5 & SYNOPSIS & Corrective & $\mathrm{O} 11, \mathrm{O} 12$ & {$[4]$} \\
\hline 6 & Urban water planning and policy making & Preventive & $\mathrm{S} 1, \mathrm{~S} 2, \mathrm{~S} 5, \mathrm{~S} 8, \mathrm{FE} 2$ & [75] \\
\hline 7 & Maps of vulnerability & Preventive & $\mathrm{O} 4$ & [82] \\
\hline 8 & The Environmental Protection Agency Network (EPANET) & Preventive & T5 & [23] \\
\hline 9 & Bayesian network (a probabilistic graphical model) & Corrective & $\mathrm{O} 10$ & [7] \\
\hline 10 & Monte Carlo simulation & Corrective & $\mathrm{O} 4$ & {$[66,69]$} \\
\hline 11 & Socio-ecological systems approach & Preventive & E2, E3 & [83] \\
\hline 12 & Spatial modelling & Corrective & E2 & [84] \\
\hline 13 & Intervention's framework & Preventive & $\mathrm{T} 8, \mathrm{O} 12$ & {$[4]$} \\
\hline 14 & Ultrafiltration technology & Corrective & E6 & {$[45]$} \\
\hline 15 & The Water Network Tool for Resilience (WNTR) & Preventive & T6, O13 & [85] \\
\hline 16 & Awareness of infrastructure resilience and role of media & Preventive & $\mathrm{T} 4, \mathrm{~S} 9, \mathrm{O} 6, \mathrm{O} 8$ & [36] \\
\hline 17 & Coordination between stakeholders & Corrective & FE3, FE6 & [70] \\
\hline 18 & Protection, accommodation, and retreatment of infrastructure & Corrective & $\mathrm{T} 3$ & [65] \\
\hline 19 & Plantation of deep-rooted natural flora and cropping & Preventive & E6 & [53] \\
\hline 20 & $\begin{array}{c}\text { Minimizing nutrient losses, soil erosion and disposal of } \\
\text { pesticides }\end{array}$ & Preventive & E8 & [12] \\
\hline 21 & Capital Investment & Corrective & T1, FE1 & [57] \\
\hline 22 & $\begin{array}{l}\text { Use of infiltration wells and pits and prohibiting discharge of } \\
\text { drinking water sources into sanitary protection zones }\end{array}$ & Preventive & O7 & [45] \\
\hline 23 & Public participation, critical thinking & Corrective & S6, S7, O6 & {$[12,53]$} \\
\hline 24 & Comprehensive analysis of loads and inundations & Corrective & E2 & [16] \\
\hline 25 & Increasing the storage capacity of wastewater collection system & Preventive & $\mathrm{E} 8, \mathrm{~T} 9$ & {$[25]$} \\
\hline 26 & Implementing Green Infrastructure (GI) approach & Preventive & E7 & {$[22]$} \\
\hline 27 & Efficient pond sand filters & Preventive & E10, T11 & {$[45]$} \\
\hline 28 & Implementing appropriate policies and measures & Preventive & $\mathrm{T} 2, \mathrm{~T} 9, \mathrm{~T} 12, \mathrm{O} 5, \mathrm{O} 10$ & {$[4,33]$} \\
\hline 29 & Uninterrupted community engagement & Corrective & S4 & [86] \\
\hline 30 & Accurate sustainable system planning & Corrective & O3 & {$[68]$} \\
\hline
\end{tabular}

As presented in Table 7, a Geographic Information System (GIS) prevents the challenges of aging infrastructure (T1), the interdisciplinary nature of infrastructure (T4), and physical threats (T6) by transforming and integrating geographical data and value judgments [79]. GIS may be used to categorize the shape, age, and condition of sewage and the wastewater infrastructure and give managers and engineers a graphical representation of the attributes. It can also be used to support a wastewater system and local conditions, as well as define the most vulnerable manholes and pipes in a county's wastewater system [57]. It is predicted that GIS solutions for wastewater and sewage utilities will become the norm in the next decade.

Table 7 depicts that examining decisions on management techniques is a corrective action that addresses the challenges of climate change (E1), droughts (E4), earthquakes 
(E5), and direct and indirect lack of water (E9). As we cannot usually foresee natural catastrophes and their severity, it is vital to be prepared for any type of disaster, and the construction of sustainable and resilient wastewater structures is critical [15]. To assess resilience, decisions on management techniques and technology for water and sanitation services must be examined for their sensitivity and adaptive capabilities [29].

Mary Douglas's Culture Theory is another preventive approach that is shown in Table 7. It can be used to manage rural water points and to investigate how it may be operationalized in pluralist arrangements in scaling up different management cultures [84]. It describes how various management cultures deal with organizational, financial, structural, and environmental hazards [85], and illustrates the possibility for risk-sharing in a professional service provider and decreasing uncertainty by enabling quick reactions to waterpoint failures via newly discovered knowledge flows [66].

Table 7 shows that educating people about disaster responses and recovery strategies can help prevent a community's lack of trust, negative public opinion, and an inadequate number of qualified human resources. As the lack of public awareness and knowledge about hazards was one of the potential challenges, the implementation of measures to educate people about disaster response and recovery is vital, as being knowledgeable about available resources and how to access them will enable them to cope with the fallout from disasters $[80,81]$.

Table 7 also indicates that SYNOPYSIS could be a corrective approach for addressing the challenges of shortages of supporting tools and systems (O11) and lack of an integrated framework and technological solutions (O12). It is a software package for synchronous optimization and simulation of urban wastewater systems that contains sewage system, treatment plant, and river sub-models that are largely based on modelling techniques [4]. It also shows how typical standards software might produce erroneous results when assessing the functioning of urban wastewater systems under varied conditions [2].

\section{Conclusions}

This study sought to determine the challenges to a resilient drinking water and wastewater infrastructure. The database identified 51 challenges and classified them into five categories: environmental, technical and infrastructure, organizational, social, and financial and economic. A total of thirty (30) strategies and approaches that effectively address the challenges were determined and categorized into preventive and corrective groups, based on implementation time.

The results revealed that climate change was the most referred to barrier in the environmental category, as changes in the climate create new obstacles and lengthen the reconstruction process. An aging infrastructure was the most frequently mentioned barrier in the technical and infrastructure category. Many structures are reaching the end of their lifetime, and a considerable financial investment will be needed to keep them back in excellent condition. The most significant barrier of the social category was population growth. Due to the increase in the population, it is increasingly difficult to ensure the quality and quantity of water. The top-ranked barrier in the organization category was the lack of data reliability, quality, and accessibility. Lack of reliable data has always been a problem in quantifying resilience and negatively impacts society. Finally, the lack of infrastructure capital was the top-ranked barrier in the financial and economic category. Insufficient capital causes major challenges by delaying resources such as materials, machinery, and workforce. Among the 30 identified strategies and approaches, 17 are preventive and 13 are corrective. The findings of this paper will assist engineering research communities in developing more accurate, quantitative, and practical resilience measures for critical water infrastructures. While great care was taken to conduct a thorough and reliable study, there are a few limitations that should be mentioned. The challenges of the financial and economic category were not studied in detail by the researchers, but because of their significance, it is recommended that additional attention be paid to them in future studies. 
Additionally, the dynamic relationships between the various challenges and strategies must be investigated.

Author Contributions: Conceptualization, A.P., E.S. and N.A.; methodology, A.P.; writing—original draft preparation, A.P., N.A., and E.S.; writing-review and editing, S.K.; supervision, S.K. All authors have read and agreed to the published version of the manuscript.

Funding: This research received no external funding.

Conflicts of Interest: The authors declare no conflict of interest.

\section{References}

1. Greer, R.A. A review of public water infrastructure financing in the United States. Wiley Interdiscip. Rev. Water 2020, 7, 1472. [CrossRef]

2. Juan-García, P.; Butler, D.; Comas, J.; Darch, G.; Sweetapple, C.; Thornton, A.; Corominas, L. Resilience theory incorporated into urban wastewater systems management. State of the art. Water Res. 2017, 115, 149-161. [CrossRef]

3. Rouhanizadeh, B.; Kermanshachi, S.; Dhamangaonkar, V.S. Reconstruction of Critical and Interdependent Infrastructures due to Catastrophic Natural Disasters: Lessons Learned. In Proceedings of the ASCE Construction Research Congress (CRC 2020), Tempe, AZ, USA, 8-10 March 2020.

4. Butler, D.; Ward, S.; Sweetapple, C.; Astaraie-Imani, M.; Diao, K.; Farmani, R.; Fu, G. Reliable, resilient and sustainable water management: The Safe \& SuRe approach. Glob. Chall. 2016, 1, 63-77. [CrossRef]

5. Adepu, N.; Kermanshachi, S.; Safapour, E.; Pamidimukkala, A. Challenges and Risks in Resilience Management of Water and Wastewater Infrastructures. In Proceedings of the ASCE Construction Research Congress (CRC), Arlington, VA, USA, 9-12 March 2022.

6. Fischer, A.; Hope, R.; Manandhar, A.; Hoque, S.; Foster, T.; Hakim, A.; Islam, S.; Bradley, D. Risky responsibilities for rural drinking water institutions: The case of unregulated self-supply in Bangladesh. Glob. Environ. Chang. 2020, 65, 102152. [CrossRef]

7. Pagano, A.; Giordano, R.; Portoghese, I.; Fratino, U.; Vurro, M. A Bayesian vulnerability assessment tool for drinking water mains under extreme events. Nat. Hazards 2014, 74, 2193-2227. [CrossRef]

8. NIAC. Critical Infrastructure Resilience: Final Report and Recommendations; National Infrastructure Advisory Council: Washington, DC, USA, 2009.

9. Nipa, T.J.; Kermanshachi, S.; Ramaji, I. Comparative analysis of strengths and limitations of infrastructure resilience measurement methods. In Proceedings of the 7th CSCE International Construction Specialty Conference (ICSC), Montreal, QU, Canada, 12-15 June 2019.

10. Croope, S.V.; McNeil, S. Improving Resilience of Critical Infrastructure Systems Postdisaster. Transp. Res. Rec. J. Transp. Res. Board 2011, 2234, 3-13. [CrossRef]

11. Kermanshachi, S.; Thakur, R.; Govan, P. Discovering the Impact of Late Change Orders and Rework on Labor Productivity: A Water Treatment Case Study Analysis Using System Dynamics Modeling. In Proceedings of the Construction Research Congress, New Orleans, LA, USA, 2-4 April 2018. [CrossRef]

12. Shanaghan, P.E. Assessing Drinking Water Infrastructure Need. J. Am. Water Work. Assoc. 2012, 104, 14-15. [CrossRef]

13. Rouhanizadeh, B.; Kermanshachi, S.; Nipa, T.J. Identification, Categorization, and Weighting of Barriers to Timely Post-Disaster Recovery Process. In Computing in Civil Engineering 2019: Smart Cities, Sustainability, and Resilience; American Society of Civil Engineers: Reston, VA, USA, 2019; pp. 41-49. [CrossRef]

14. Uy, N.; Shaw, R. Ecosystem resilience and community values: Implications to ecosystem-based adaptation. J. Disaster Res. 2013, 8, 201-202.

15. Leichenko, R.; McDermott, M.; Bezborodko, E. Barriers, Limits and Limitations to Resilience. J. Extreme Events 2015, 2, 1550002. [CrossRef]

16. Wadey, M.P.; Nicholls, R.J.; Hutton, C. Coastal Flooding in the Solent: An Integrated Analysis of Defences and Inundation. Water 2012, 4, 430-459. [CrossRef]

17. Nazarnia, H.; Nazarnia, M.; Sarmasti, H.; Wills, W.O. A Systematic Review of Civil and Environmental Infrastructures for Coastal Adaptation to Sea Level Rise. Civ. Eng. J. 2020, 6, 1375-1399. [CrossRef]

18. Renner, R.C. Climate change, extreme weather, and water utilities: Preparing for the new normal. J. Am. Water Work. Assoc. 2013, 105, 44-51. [CrossRef]

19. Young, I.; Smith, B.A.; Fazil, A. A systematic review and meta-analysis of the effects of extreme weather events and other weather-related variables on Cryptosporidium and Giardia in fresh surface waters. J. Water Health 2014, 13, 1-17. [CrossRef] [PubMed]

20. Davis, C.A. Los Angeles water supply impacts from a M7.8 San Andreas Fault earthquake scenario. J. Water Supply Res. Technol. 2010, 59, 408-417. [CrossRef]

21. Balaei, B.; Wilkinson, S.; Potangaroa, R.; McFarlane, P. Investigating the technical dimension of water supply resilience to disasters. Sustain. Cities Soc. 2020, 56, 102077. [CrossRef] 
22. Dhakal, K.P.; Chevalier, L.R. Urban Stormwater Governance: The Need for a Paradigm Shift. Environ. Manag. 2016, 57, 1112-1124. [CrossRef]

23. Thompson, S.L.; Casman, E.; Fischbeck, P.; Small, M.J.; VanBriesen, J.M. Vulnerability Assessment of a Drinking Water Distribution System: Implications for Public Water Utilities. In Proceedings of the World Environmental and Water Resources Congress 2007: Restoring Our Natural Habitat, Tampa, FL, USA, 15-19 May 2007; pp. 1-12. [CrossRef]

24. Clark, R.M.; Yang, Y.J.; Impellitteri, C.; Haught, R.C.; Schupp, D.; Panguluri, S.; Krishnan, E.R. Controlling Disinfection Residual Losses in Drinking Water Distribution Systems: Results from Experimental Studies. Water Distrib. Syst. Anal. 2008, $2008,1-12$. [CrossRef]

25. Fu, X.; Goddard, H.; Wang, X.; Hopton, M.E. Development of a scenario-based stormwater management planning support system for reducing combined sewer overflows (CSOs). J. Environ. Manag. 2019, 236, 571-580. [CrossRef]

26. Rygaard, M.; Binning, P.J.; Albrechtsen, H.-J. Increasing urban water self-sufficiency: New era, new challenges. J. Environ. Manag. 2011, 92, 185-194. [CrossRef]

27. Zhang, J. The impact of water quality on health: Evidence from the drinking water infrastructure program in rural China. J. Health Econ. 2012, 31, 122-134. [CrossRef]

28. Larsen, T.A.; Hoffmann, S.; Lüthi, C.; Truffer, B.; Maurer, M. Emerging solutions to the water challenges of an urbanizing world. Science 2016, 352, 928-933. [CrossRef]

29. Velasco, M.; Russo, B.; Martínez, M.; Malgrat, P.; Monjo, R.; Djordjevic, S.; Fontanals, I.; Vela, S.; Cardoso, M.A.; Buskute, A. Resilience to Cope with Climate Change in Urban Areas-A Multisectorial Approach Focusing on Water-The RESCCUE Project. Water 2018, 10, 1356. [CrossRef]

30. Ahmed, I. Resilient Housing Reconstruction in the Developing World. In Urban Planning for Disaster Recovery; Elsevier: Amsterdam, The Netherlands, 2017; pp. 171-188. [CrossRef]

31. Van Leeuwen, K.; Hofman, J.; Driessen, P.P.J.; Frijns, J. The Challenges of Water Management and Governance in Cities. Water 2019, 11, 1180. [CrossRef]

32. Osei-Kyei, R.; Tam, V.; Ma, M.; Mashiri, F. Critical review of the threats affecting the building of critical infrastructure resilience. Int. J. Disaster Risk Reduct. 2021, 60, 102316. [CrossRef]

33. Kang, H. Challenges for water infrastructure asset management in South Korea. Hydrol. Res. 2019, 21, 934-944. [CrossRef]

34. Dominguez, D.; Gujer, W. Evolution of a wastewater treatment plant challenges traditional design concepts. Water Res. 2006, 40, 1389-1396. [CrossRef]

35. Balkema, A.J.; A Preisig, H.; Otterpohl, R.; Lambert, F.J. Indicators for the sustainability assessment of wastewater treatment systems. Urban Water 2002, 4, 153-161. [CrossRef]

36. Alderson, D.L. Overcoming barriers to greater scientific understanding of critical infrastructure resilience. In Handbook on Resilience of Socio-Technical Systems; Edward Elgar Publishing: Northampton, MA, USA, 2019; pp. 66-88. [CrossRef]

37. Seager, T.P.; Clark, S.S.; Eisenberg, D.A.; Thomas, J.E.; Hinrichs, M.M.; Kofron, R.; Jensen, C.N.; McBurnett, L.R.; Snell, M.; Alderson, D.L. Redesigning Resilient Infrastructure Research. In Resilience and Risk; Springer: Berlin/Heidelberg, Germany, 2017; pp. 81-119. [CrossRef]

38. Boryczko, K.; Piegdoń, I.; Szpak, D.; Żywiec, J. Risk Assessment of Lack of Water Supply Using the Hydraulic Model of the Water Supply. Resources 2021, 10, 43. [CrossRef]

39. Taormina, R.; Galelli, S.; Tippenhauer, N.O.; Salomons, E.; Ostfeld, A. Characterizing Cyber-Physical Attacks on Water Distribution Systems. J. Water Resour. Plan. Manag. 2017, 143, 04017009. [CrossRef]

40. Bakalos, N.; Voulodimos, A.; Doulamis, N.; Doulamis, A.; Ostfeld, A.; Salomons, E.; Caubet, J.; Jimenez, V.; Li, P. Protecting Water Infrastructure From Cyber and Physical Threats: Using Multimodal Data Fusion and Adaptive Deep Learning to Monitor Critical Systems. IEEE Signal Process. Mag. 2019, 36, 36-48. [CrossRef]

41. Matthews, J.C. Disaster Resilience of Critical Water Infrastructure Systems. J. Struct. Eng. 2016, 142, C6015001. [CrossRef]

42. Yazdani, A.; Jeffrey, P. Water distribution system vulnerability analysis using weighted and directed network models. Water Resour. Res. 2012, 48. [CrossRef]

43. Nazarnia, H.; Sarmasti, H.; Wills, W.O. Application of household disruption data to delineate critical infrastructure resilience characteristics in the aftermath of disaster: A case study of Bhaktapur, Nepal. Saf. Sci. 2019, 121, 573-579. [CrossRef]

44. Bai, H.; Sadiq, R.; Najjaran, H.; Rajani, B. Condition Assessment of Buried Pipes Using Hierarchical Evidential Reasoning Model. J. Comput. Civ. Eng. 2008, 22, 114-122. [CrossRef]

45. Harun, M.A.Y.A.; Kabir, G.M.M. Evaluating pond sand filter as sustainable drinking water supplier in the Southwest coastal region of Bangladesh. Appl. Water Sci. 2012, 3, 161-166. [CrossRef]

46. Malalgoda, C.; Amaratunga, D.; Haigh, R. Challenges in Creating a Disaster Resilient Built Environment. Procedia Econ. Finance 2014, 18, 736-744. [CrossRef]

47. Rouhanizadeh, B.; Kermanshachi, S.; Nipa, T.J. Exploratory analysis of barriers to effective post-disaster recovery. Int. J. Disaster Risk Reduct. 2020, 50, 101735. [CrossRef]

48. Mostafavi, A.; Ganapati, N.E.; Nazarnia, H.; Pradhananga, N.; Khanal, R. Adaptive Capacity under Chronic Stressors: Assessment of Water Infrastructure Resilience in 2015 Nepalese Earthquake Using a System Approach. Nat. Hazards Rev. 2018, 19, 05017006. [CrossRef] 
49. Scott, C.A.; Bailey, C.J.; Marra, R.P.; Woods, G.J.; Ormerod, K.J.; Lansey, K. Scenario Planning to Address Critical Uncertainties for Robust and Resilient Water-Wastewater Infrastructures under Conditions of Water Scarcity and Rapid Development. Water 2012, 4, 848-868. [CrossRef]

50. Singh, V.; Pandey, A. Urban water resilience in Hindu Kush Himalaya: Issues, challenges and way forward. Hydrol. Res. 2019, 22, 33-45. [CrossRef]

51. Koop, S.H.A.; Van Leeuwen, C.J. The challenges of water, waste and climate change in cities. Environ. Dev. Sustain. 2017, 19, 385-418. [CrossRef]

52. Lim, S.-R.; Suh, S.; Kim, J.-H.; Park, H.S. Urban water infrastructure optimization to reduce environmental impacts and costs. J. Environ. Manag. 2010, 91, 630-637. [CrossRef]

53. Kloosterman, R.A.; Veeneman, W.; Van Der Hoek, J.P. Sustainable Societal Infrastructures: A Resilient Approach to Prevent Conflicting Claims of Drinking Water and Other Infrastructures. Sustainability 2020, 12, 785. [CrossRef]

54. van Laere, J.; Berggren, P.; Gustavsson, P.; Ibrahim, O.; Johansson, B.; Larsson, A.; Lindqwister, T.; Olsson, L.; Wiberg, C. Challenges for critical infrastructure resilience: Cascading effects of payment system disruptions. In Proceedings of the 14th International Conference on Information Systems for Crisis Response and Management (ISCRAM2017), Albi, France, 21-24 May 2017; pp. 281-292.

55. Chou, J.-S.; Wu, J.-H. Success factors of enhanced disaster resilience in urban community. Nat. Hazards 2014, 74, 661-686. [CrossRef]

56. Apurva, P.; Sharareh, K.; Elnaz, S. Challenges in Post-Disaster Housing Reconstruction: Analysis of Urban vs. Rural Communities. In Proceedings of the Creative Construction e-Conference, Opatija, Croatia, 28 June-1 July 2020; pp. 103-110. [CrossRef]

57. Faust, A.K.M.; Kaminsky, M.J.A. Building Water and Wastewater System Resilience to Disaster Migration: Utility Perspectives. J. Constr. Eng. Manag. 2017, 143, 04017058. [CrossRef]

58. Olsson, E.-K. Crisis Communication in Public Organisations: Dimensions of Crisis Communication Revisited. J. Contingencies Crisis Manag. 2014, 22, 113-125. [CrossRef]

59. Bahrini, R.; Qaffas, A.A. Impact of Information and Communication Technology on Economic Growth: Evidence from Developing Countries. Economies 2019, 7, 21. [CrossRef]

60. Dong, X.; Guo, H.; Zeng, S. Enhancing future resilience in urban drainage system: Green versus grey infrastructure. Water Res. 2017, 124, 280-289. [CrossRef]

61. Pandey, C.L. Making communities disaster resilient: Challenges and prospects for community engagement in Nepal. Disaster Prev. Manag. Int. J. 2018, 28, 106-118. [CrossRef]

62. Roy, S.B.; Chen, L.; Girvetz, E.H.; Maurer, E.; Mills, W.B.; Grieb, T.M. Projecting Water Withdrawal and Supply for Future Decades in the U.S. under Climate Change Scenarios. Environ. Sci. Technol. 2012, 46, 2545-2556. [CrossRef]

63. Schlosser, C.A.; Strzepek, K.; Gao, X.; Fant, C.; Blanc, É.; Paltsev, S.; Jacoby, H.; Reilly, J.; Gueneau, A. The future of global water stress: An integrated assessment. Earth's Future 2014, 2, 341-361. [CrossRef]

64. Matthews, J.C.; Piratla, K.; Matthews, E. Disaster Resilience of Drinking Water Infrastructure Systems to Multiple Hazards. In Proceedings of the Structures Congress, Boston, MA, USA, 3-5 April 2014; pp. 2312-2317. [CrossRef]

65. De Almeida, B.A.; Mostafavi, A. Resilience of Infrastructure Systems to Sea-Level Rise in Coastal Areas: Impacts, Adaptation Measures, and Implementation Challenges. Sustainability 2016, 8, 1115. [CrossRef]

66. Koehler, J.; Rayner, S.; Katuva, J.; Thomson, P.; Hope, R. A cultural theory of drinking water risks, values and institutional change. Glob. Environ. Chang. 2018, 50, 268-277. [CrossRef]

67. Nizkorodov, E. Evaluating risk allocation and project impacts of sustainability-oriented water public-private partnerships in Southern California: A comparative case analysis. World Dev. 2020, 140, 105232. [CrossRef]

68. Marques, R.C.; da Cruz, N.; Pires, J. Measuring the sustainability of urban water services. Environ. Sci. Policy 2015, 54, 142-151. [CrossRef]

69. Hacker, M.E.; Kaminsky, J.; Faust, K.M. Legitimizing Involvement in Emergency Accommodations: Water and Wastewater Utility Perspectives. J. Constr. Eng. Manag. 2019, 145, 04019013. [CrossRef]

70. Bakchan, A.; Hacker, M.E.; Faust, K.M. Resilient Water and Wastewater Infrastructure Systems through Integrated HumanitarianDevelopment Processes: The Case of Lebanon's Protracted Refugee Crisis. Environ. Sci. Technol. 2021, 55, 6407-6420. [CrossRef]

71. Wang, J.; Shen, J.; Ye, D.; Yan, X.; Zhang, Y.; Yang, W.; Li, X.; Wang, J.; Zhang, L.; Pan, L. Disinfection technology of hospital wastes and wastewater: Suggestions for disinfection strategy during coronavirus Disease 2019 (COVID-19) pandemic in China. Environ. Pollut. 2020, 262, 114665. [CrossRef]

72. Pamidimukkala, A.; Kermanshachi, S. Impact of Covid-19 on field and office workforce in construction industry. Proj. Leadersh. Soc. 2021, 2, 100018. [CrossRef]

73. Pamidimukkala, A.; Kermanshachi, S.; Nipa, T.J. Impacts of COVID-19 on Health and Safety of Workforce in Construction Industry. In Proceedings of the International Conference on Transportation and Development, Virtual, 8-10 June 2021; pp. 418-430. [CrossRef]

74. Ng, S.T.; Xu, F.J.; Yang, Y.; Lu, M.; Li, J. Necessities and challenges to strengthen the regional infrastructure resilience within city clusters. Procedia Eng. 2018, 212, 198-205. [CrossRef]

75. Kayser, G.L.; Amjad, U.; Dalcanale, F.; Bartram, J.; Bentley, M.E. Drinking water quality governance: A comparative case study of Brazil, Ecuador, and Malawi. Environ. Sci. Policy 2015, 48, 186-195. [CrossRef] [PubMed] 
76. Collier, M.J.; Nedović-Budić, Z.; Aerts, J.; Connop, S.; Foley, D.; Foley, K.; Newport, D.; McQuaid, S.; Slaev, A.D.; Verburg, P. Transitioning to resilience and sustainability in urban communities. Cities 2013, 32, S21-S28. [CrossRef]

77. Rouhanizadeh, B.; Kermanshachi, S. Comparative Analysis of Public's and Decision-Makers' Perspectives on Socioeconomic Barriers Causing Delay in Post-Disaster Recovery Processes. In Proceedings of the Construction Research Congress 2020: Infrastructure Systems and Sustainability, Opatija, Croatia, 28 June-1 July 2020; pp. 856-864. [CrossRef]

78. Siagian, T.H.; Purhadi, P.; Suhartono, S.; Ritonga, H. Social vulnerability to natural hazards in Indonesia: Driving factors and policy implications. Nat. Hazards 2013, 70, 1603-1617. [CrossRef]

79. Friedrich, E.; Kretzinger, D. Vulnerability of wastewater infrastructure of coastal cities to sea level rise: A South African case study. Water SA 2012, 38, 755-764. [CrossRef]

80. Johansen, C.; Horney, J.; Tien, I. Metrics for Evaluating and Improving Community Resilience. J. Infrastruct. Syst. 2017, 23, 04016032. [CrossRef]

81. Sekercioglu, M.F.; White, J.; Shrubsole, D.; Baxter, J. Towards a Sustainable Small Non-Community Drinking Water System in Ontario: Owners' Risk Awareness and Perceptions to Water Safety. J. Sustain. Dev. 2018, 11, 71. [CrossRef]

82. Hoque, M.A.; Scheelbeek, P.F.D.; Vineis, P.; Khan, A.E.; Ahmed, K.M.; Butler, A.P. Drinking water vulnerability to climate change and alternatives for adaptation in coastal South and South East Asia. Clim. Chang. 2016, 136, 247-263. [CrossRef]

83. Hoque, M.A.-A.; Ahmed, N.; Pradhan, B.; Roy, S. Assessment of coastal vulnerability to multi-hazardous events using geospatial techniques along the eastern coast of Bangladesh. Ocean Coast. Manag. 2019, 181, 104898. [CrossRef]

84. Allen, T.R.; Crawford, T.; Montz, B.; Whitehead, J.; Lovelace, S.; Hanks, A.D.; Christensen, A.R.; Kearney, G.D. Linking Water Infrastructure, Public Health, and Sea Level Rise: Integrated Assessment of Flood Resilience in Coastal Cities. Public Work. Manag. Policy 2018, 24, 110-139. [CrossRef]

85. Klise, K.A.; Bynum, M.; Moriarty, D.; Murray, R. A software framework for assessing the resilience of drinking water systems to disasters with an example earthquake case study. Environ. Model. Softw. 2017, 95, 420-431. [CrossRef]

86. Arbon, P. Developing a model and tool to measure community disaster resilience. Aust. J. Emerg. Manag. 2014, 29 , 12-16. 